\title{
EARTHWORM (EISENIA FETIDA) BIOASSAY TO ASSESS THE POSSIBLE EFFECTS OF PLATINUM TAILINGS DISPOSAL FACILITIES ON THE ENVIRONMENT ALONG A GRADIENT
}

\author{
M.S. MABOETA* ${ }^{*}$ L. VAN RENSBURG - P.J. JANSEN VAN RENSBURG \\ School for Environmental Sciences and Development, North-West University, Potchefstroom \\ Campus, Private Bag X6001, Potchefstroom 2520 South Africa \\ *Corresponding author \\ e-maildrkmsm@puk.ac.za \\ (Received $11^{\text {th }}$ July 2005 ; accepted $12^{\text {th }}$ June 2007)
}

\begin{abstract}
Platinum mines produce large amounts of inorganic tailings containing high levels of metals which are disposed of on tailings disposal facilities (TDFs) and there is no information available on their possible effects on the surrounding terrestrial environment. The aim of this study was to do an earthworm bioassay of soils along a gradient from a TDF over a period of 28 days in terms of growth, reproduction and metal accumulation. After 28 days the earthworms in the soil collected up to $1 \mathrm{~km}$ away from the TDF showed a significant $(\mathrm{P}<0.05)$ decrease in bodyweight and in the soil $2-5 \mathrm{~km}$ away showed no effect. The earthworms in the soil collected $15 \mathrm{~km}$ away from the TDF showed a significant $(\mathrm{P}<0.05)$ increase in bodyweight. The mean hatching success of cocoons was significantly $(\mathrm{P}<0.05)$ higher in the soils further away from the TDF viz. $15 \mathrm{~km}>3-5 \mathrm{~km}>2-0 \mathrm{~km}$. Cr, Cu, Ni and $\mathrm{Zn}$ concentrations in the soils collected in the soils on the platinum TDF (TDF - $15 \mathrm{~km}$ in the case of Zn) were higher, while Cd, $\mathrm{Co}$ and $\mathrm{Pb}$ were lower when compared to screening benchmarks proposed by the U.S. Dept. of Energy. The presence of these metals in a mixture, however, makes it extremely difficult to assess their effects. All of the metals had low bioconcentration factors (BCFs) viz. < $0.01(\mathrm{CR}, \mathrm{Ni}$ and $\mathrm{Pb}), 0.01(\mathrm{Co})$, $0.33-0.5(\mathrm{Cd}), 0.01-0.08(\mathrm{Cu})$ and $0.18-0.29(\mathrm{Zn})$. It can be concluded that platinum mining, with TDFs as source of contamination, has negative effects on the environment but further studies are needed to assess the exact extent of these effects.
\end{abstract}

Keywords: bioassay; earthworms; Eisenia fetida; metals; platinum mining

\section{Introduction}

Mining activities in South Africa contribute to more than $70 \%$ of the solid waste stream [1] and use an estimated 25000 ha of land as dumping areas [2]. The country produces $50 \%$ of the world's platinum and holds $55 \%$ of global reserves, of which most $(>70 \%)$ is situated in the North-West Province of South Africa [3]. These areas are therefore inherently associated with the wastes produced by these mines. At one such platinum mine (second largest producer in South Africa) large amounts of inorganic tailings are produced, consisting mainly of sand and silt, which is disposed of on tailings disposal facilities (TDFs). From a previous study done by Van Rensburg and Morgenthal [4] it was evident that these tailings contained high levels of metals compared to the standards proposed by the South African Department of Water Affairs and Forestry [5]. TDFs, therefore pose a range of possible environmental impacts including air, dust and groundwater pollution. At present there is, however, no information available on the possible effects platinum TDFs might have on the surrounding terrestrial environment.

Analytical methods used to measure the levels of contaminants in soils may result in misleading indications of the bioavailability of the contaminants [6,7]. The use of biological indicators to provide information on the environmental risks of contaminated 
sites has therefore been proposed as a tool in risk assessment by the United States Environmental Protection Agency [USEPA] [8] and the Canadian Government's contaminated sites remediation program [9]. At present there are, however, no guidelines or policies in South Africa regarding levels of contaminants in soil that would not pose environmental risks. In an overview on soil biology and biochemistry in South Africa, Haynes and Graham [10] ascribed this lack in guidelines to the paucity of research done in this field.

Bioassays, using earthworms and soil from contaminated field sites, are recommended [11] for determining the actual toxicity and risk of contaminated soil and have been used in numerous studies [12, 13, etc.] since they provide an index to the bioavailability of contaminants present in these soils. Further, growth and reproduction of the earthworms can provide additional information about the sublethal effects on the worms and potential environmental hazards, since earthworms can be seen as sentinel soil organisms.

The aim of this study was to do a bioassay of soils along a gradient from a TDF to assess the possible impact it has on the surrounding terrestrial environment. This was achieved by collecting soils from the field, determining its metal concentrations and exposing earthworms (Eisenia fetida) to it in a 28-day bioassay. Further, to evaluate the changes in biomass and reproduction of the earthworms to assess sublethal effects on them, as well as metal contents of their body tissues.

\section{Materials and methods}

Tests were performed according to guidelines formulated by the Office of Prevention, Pesticides and Toxic Substances [14] a sub directorate of the USEPA.

A random sampling design was used to obtain three composite samples per site (each composite sample consisting of 6 subsamples $)$ of the topsoil $(0-15 \mathrm{~cm})$ from each of the sites investigated viz. 0- (on the toe of the TDF), 1-, 2-, 3-, 4-, 5- and $15 \mathrm{~km}$, the last serving as reference ("control") for the purpose of the study. The collected soils were air dried after collection and sieved $(<2 \mathrm{~mm})$ before it was moistened with distilled water to $60 \%$ (by weight) moisture content. The substrate was placed into plastic containers $(15 \times 10 \times 5 \mathrm{~cm})$, covered with a piece of plastic before putting on a perforated lid, and kept in an environmental chamber $\left(20^{\circ} \mathrm{C}\right)$ for 48 hours to stabilise, before introducing the earthworms. The $\mathrm{pH}$ of the soil was determined in the 1:2 extract with a calibrated $\mathrm{pH} /$ conductivity meter (Radiometer PHM 80, Copenhagen).

The breeding stock of E. fetida used in this study was obtained from a local worm breeder in the Potchefstroom (North-West Province of South Africa) and maintained on cattle manure at a temperature of $20^{\circ} \mathrm{C}\left( \pm 1^{\circ} \mathrm{C}\right)$. Only mature clitellate worms were used for the purposes of this investigation.

Ten earthworms were placed in each of the three replicate containers filled with 500 $\mathrm{g}$ of the prepared soils. Feeding of the worms comprised sprinkling $5 \mathrm{~g}$ of dried cattle manure per container per week. Metal concentrations in the control and exposure group substrates were determined prior to the start of the experiment. The biomass of the earthworms was determined at the start of the experiment (day 0) and at the end (day $28)$ and the moisture content $(60 \%)$ and $\mathrm{pH}(7)$ of the substrates was monitored every 7 days.

Cocoon viability was determined by harvesting 15 cocoons from each container and placing them in multidishes filled with distilled water. The water in these dishes were 
changed every third day to prevent bacterial growth, which could impact negatively on the results. The number of hatched cocoons was recorded over a period of four weeks.

Mortality was determined by counting the number of dead earthworms. Worms were considered dead if they lacked movement and did not respond to a definite tactile stimulus to the anterior end. Because earthworms tend to disintegrate quickly after death, absent earthworms were considered to have died.

\section{Metal analysis}

At termination of the experiment four earthworms per replicate $(n=12)$ were removed from the substrate. These worms were placed on wet filter paper in Petri dishes for a period of $48 \mathrm{~h}$ to allow the depuration of their gut contents. This was done to determine the actual metal content in the body tissues in order to calculate bioconcentration factors (BCFs). After this 48-h period the worms were washed in distilled water, dried on paper towels and killed by freezing. They were individually weighed and frozen $\left(-74^{\circ} \mathrm{C}\right)$ in polypropylene vials for metal analysis at a later stage. Three samples per replicate $(n=9)$ of the substrate were also removed, placed in plastic bags and refrigerated until metal analysis. Worms and soil samples were digested as described by Katz \& Jennis [15] and analysed on an Agilent 7500c Inductive coupled plasma mass-spectrometer (ICP-MS).

\section{Statistical analysis of data}

The data in this study was analysed by using the SigmaStat ${ }^{\circledR}$ computer software package and all values presented as the mean \pm SD (standard deviation). The probability levels used for statistical significance were $\mathrm{P}<0.05$ and parametric or nonparametric tests were used to compare groups.

\section{Results and discussion}

At no stage during the study were any mortality observed and the results regarding changes in bodyweight and mean number of cocoons hatched are summarised in Table 1. On day one (initiation of experiment) there was no significant $(\mathrm{P}>0.05)$ difference between the bodyweights of the earthworms introduced into the different soils. After 28 days (termination of experiment) the earthworms in the soil collected up to $1 \mathrm{~km}$ away from the TDF showed a significant $(\mathrm{P}<0.05)$ decrease in bodyweight and in the soil $2-5 \mathrm{~km}$ showed no effect. The earthworms in the soil collected $15 \mathrm{~km}$ away from the TDF showed a significant $(\mathrm{P}<0.05)$ increase in bodyweight. The mean hatching success of cocoons, which gives a good representation of reproductive success, was significantly $(\mathrm{P}<0.05)$ higher in the soils further away from the TDF viz. $15 \mathrm{~km}>$ $3-5 \mathrm{~km}>2-0 \mathrm{~km}$. Reproductive success as indicator was therefore a more sensitive parameter than growth insofar as to assess the effects of platinum mining on the environment. 
Table 1. Mean bodyweight $(g)$ and percentage weight change of earthworms $(n=30)$ exposed to soils collected at different distances (in $\mathrm{km}$ ) from the tailings disposal facility (TDF) at the start (day 1) and end (day 28) of the bioassay, as well as mean number and hatching success of cocoons produced.

\begin{tabular}{lllll}
\hline Site & Day 1 & Day 28 & Weight change (\%) & $\begin{array}{l}\text { Mean \% } \\
\text { cocoons hatched }(\boldsymbol{n}=\mathbf{1 5})\end{array}$ \\
\hline TDF & $0.42 \pm 0.07^{\mathrm{a}}$ & $0.37 \pm 0.05^{\mathrm{a}^{\mathrm{*}}}$ & $-13.08^{*}$ & $30.75 \pm 3.42^{\mathrm{a}}$ \\
$\mathbf{1}$ & $0.41 \pm 0.10^{\mathrm{a}}$ & $0.36 \pm 0.08^{\mathrm{a}^{*}}$ & $-12.67^{*}$ & $31.29 \pm 0.93^{\mathrm{a}}$ \\
$\mathbf{2}$ & $0.44 \pm 0.07^{\mathrm{a}}$ & $0.40 \pm 0.08^{\mathrm{a}}$ & -5.51 & $34.68 \pm 1.22^{\mathrm{a}}$ \\
$\mathbf{3}$ & $0.39 \pm 0.07^{\mathrm{a}}$ & $0.38 \pm 0.06^{\mathrm{a}}$ & -2.54 & $54.24 \pm 2.52^{\mathrm{b}}$ \\
$\mathbf{4}$ & $0.40 \pm 0.08^{\mathrm{a}}$ & $0.39 \pm 0.08^{\mathrm{a}}$ & -2.09 & $54.21 \pm 6.5^{\mathrm{b}}$ \\
$\mathbf{5}$ & $0.42 \pm 0.08^{\mathrm{a}}$ & $0.41 \pm 0.07^{\mathrm{a}}$ & -1.60 & $56.02 \pm 4.7^{\mathrm{b}}$ \\
$\mathbf{1 5}$ & $0.40 \pm 0.04^{\mathrm{a}}$ & $0.45 \pm 0.08^{\mathrm{b}}$ & 12.50 & $74.32 \pm 1.13^{\mathrm{c}}$ \\
\hline
\end{tabular}

* significantly different from initial bodyweight $(\mathrm{P}<0.05)$

${ }^{a, b, c}$ Means with the same letter were not significantly different $(\mathrm{P}>0.05)$

The metal concentrations and $\mathrm{pH}$ measured in the soils and earthworm body tissues are summarised in Table 2, which includes screening benchmarks (SBs) proposed by the U.S. Dept. of Energy [16] as well as target concentrations (TCs) and intervention concentrations (ICs) proposed by the Dutch Government (VROM) [17]. SBs are the concentrations deemed to be of potential concern to specifically earthworms as target organisms. TCs are the levels of contamination at which there is sustainable soil quality, whilst the ICs indicates concentrations of contaminants that may seriously impair the function of human, plant and animal life. The reason for using benchmarks proposed by Efroymson et al. [16] and VROM [17] is that at present no such information is available for South African soils.

$\mathrm{Cr}, \mathrm{Cu}, \mathrm{Ni}$ and $\mathrm{Zn}$ concentrations in the soils collected in the soils on the platinum TDF (TDF - $15 \mathrm{~km}$ in the case of Zn) were higher than the SBs and the TCs but lower than the ICs. Cr in the sites 1-15 km away from the TDF the measured concentrations were higher than the SB but lower than the TC, while the $\mathrm{Cu}$ concentrations were below the SBs and TCs for the same sites. Ni in these sites (1-15 km away from the TDF) was below the SB and IC bit higher than the TC. $\mathrm{Cd}, \mathrm{Co}$ and $\mathrm{Pb}$ were all higher than the TCs but lower than the IC and SBs for all the sites (TDF-15 km). The effects of $\mathrm{Cr}$ [18, 19], $\mathrm{Cu}$ [20, 21], $\mathrm{Ni}$ [22] and $\mathrm{Zn} \mathrm{[23]} \mathrm{on} \mathrm{either} \mathrm{growth} \mathrm{or} \mathrm{reproduction} \mathrm{of}$ earthworms has been reported on. These reported effects were, however, at higher metal concentrations than found in the present study, but it has to be taken into account that these studies were conducted using single metals as contaminants. Based on previous studies regarding $\mathrm{Cd}$ [21, 23, 24], Co [16] and $\mathrm{Pb}[21,24]$ it can be concluded that these metals should not be of concern in the soils on a gradient away from platinum TDF. The presence of these metals in a mixture, however, makes it extremely difficult to assess the effects these metals might have on earthworms since the actual toxicity is determined by the bioavailability of toxicants. The reason for this being that pollutants in mixtures might be additive, antagonistic or synergistic in the effects they have on organisms. Khalil et al. [25] e.g. concluded that the presence of $\mathrm{Cd}, \mathrm{Cu}$ and $\mathrm{Zn}$ below $\mathrm{EC}_{50}$ concentrations might affect growth negatively, but also stated that there is little agreement in the literature about metal mixture toxicity. All of the metals had low BCFs viz. < $0.01(\mathrm{CR}, \mathrm{Ni}$ and $\mathrm{Pb}), 0.01(\mathrm{Co}), 0.33-0.5(\mathrm{Cd}), 0.01-0.08(\mathrm{Cu})$ and $0.18-0.29$ $(\mathrm{Zn})$. Since these BCFs were all $<1$ it is indicative that the potential for earthworms to 
accumulate it in their body tissues are limited, which could be a consequence of the high $\mathrm{pH}$ levels of the soils (Table 2).

Table 2. Selected metal concentrations ( $\mu g^{-1}$ unless indicated otherwise) of soils (dry weight, $n=9$ ) and earthworms (E/w) utilised in soils collected at different distances (in $\mathrm{km}$ ) from the tailings disposal facility (TDF), calculated bioconcentration factors $(B C F)$ of earthworm body tissues $(n=12)$ after termination of a 28-day bioassay, screening benchmark concentrations (USDE, 1997) as well as target (TC) and intervention concentrations (IC) [VROM, 2000].

\begin{tabular}{|c|c|c|c|c|c|c|c|c|c|}
\hline & & $\mathbf{C d}$ & Co & $\mathrm{Cr}$ & $\mathrm{Cu}$ & $\mathbf{N i}$ & $\mathbf{P b}$ & Zn & pH \\
\hline USDE & & 20 & - & 0.4 & 50 & 200 & 500 & 200 & \\
\hline VROI & I (TC) & 0.8 & 9 & 100 & 36 & 35 & 85 & 140 & \\
\hline VROI & I (IC) & 12 & 240 & 380 & 190 & 210 & 530 & 720 & \\
\hline Site & & & & & & & & & \\
\hline TDF & Soil & $2.23 \pm$ & $220.00 \pm$ & $263.33 \pm$ & $67.67 \pm$ & $210.00 \pm$ & $373.33 \pm$ & $300.00 \pm$ & $8.08 \pm$ \\
\hline & & $0.28^{\mathrm{a}}$ & $20.00^{\mathrm{a}}$ & $11.55^{\mathrm{a}}$ & $18.18^{\mathrm{a}}$ & $88.88^{\mathrm{a}}$ & $41.63^{\mathrm{a}}$ & $43.59^{\mathrm{a}}$ & $0.05^{\mathrm{A}}$ \\
\hline & $\mathrm{E} / \mathrm{w}$ & $0.85 \pm$ & $2.76 \pm$ & $1.62 \pm$ & $0.98 \pm$ & $0.26 \pm$ & $0.25 \pm$ & $63.03 \pm$ & \\
\hline & & $0.41^{\mathrm{a}}$ & $1.26^{\mathrm{a}}$ & $0.37^{\mathrm{a}}$ & $0.54^{\mathrm{a}}$ & $0.13^{\mathrm{a}}$ & $0.14^{\mathrm{a}}$ & $31.98^{\mathrm{a}}$ & \\
\hline & $\mathrm{BCF}$ & 0.38 & 0.01 & $<0.01$ & 0.01 & $<0.01$ & $<0.01$ & 0.21 & \\
\hline 1 & Soil & $2.53 \pm$ & $230.00 \pm$ & $69.33 \pm$ & $32.33 \pm$ & $113.33 \pm$ & $446.67 \pm$ & $353.33 \pm$ & $7.90 \pm$ \\
\hline & & $1.10^{\mathrm{a}}$ & $30.00^{\mathrm{a}}$ & $20.40^{\mathrm{b}}$ & $1.15^{\mathrm{b}}$ & $15.28^{\mathrm{b}}$ & $30.55^{\mathrm{a}}$ & $30.55^{\mathrm{a}}$ & $0.13^{\mathrm{A}}$ \\
\hline & $\mathrm{E} / \mathrm{w}$ & $0.98 \pm$ & $2.34 \pm$ & $0.38 \pm$ & $0.94 \pm$ & $0.27 \pm$ & $0.20 \pm$ & $93.75 \pm$ & \\
\hline & & $0.43^{\mathrm{a}}$ & $0.73^{\mathrm{a}}$ & $0.18^{\mathrm{b}}$ & $0.26^{\mathrm{a}}$ & $0.12^{\mathrm{a}}$ & $0.14^{\mathrm{a}}$ & $35.13^{\mathrm{a}}$ & \\
\hline & $\mathrm{BCF}$ & 0.39 & 0.01 & $<0.01$ & 0.03 & $<0.01$ & $<0.01$ & 0.27 & \\
\hline 2 & Soil & $2.50 \pm$ & $216.67 \pm$ & $63.00 \pm$ & $18.00 \pm$ & $101.00 \pm$ & $383.33 \pm$ & $343.33 \pm$ & $8.01 \pm$ \\
\hline & & $0.17^{\mathrm{a}}$ & $20.82^{\mathrm{a}}$ & $1.00^{\mathrm{b}}$ & $3.61^{\mathrm{c}}$ & $8.54^{\mathrm{b}}$ & $87.37^{\mathrm{a}}$ & $68.07^{\mathrm{a}}$ & $0.08^{\mathrm{A}}$ \\
\hline & $\mathrm{E} / \mathrm{w}$ & $0.83 \pm$ & $2.74 \pm$ & $0.30 \pm$ & $0.84 \pm$ & $0.31 \pm$ & $0.31 \pm$ & $85.17 \pm$ & \\
\hline & & $0.56^{\mathrm{a}}$ & $1.43^{\mathrm{a}}$ & $0.03^{\mathrm{b}}$ & $0.38^{\mathrm{a}}$ & $0.19^{a}$ & $0.16^{\mathrm{a}}$ & $29.77^{\mathrm{a}}$ & \\
\hline & $\mathrm{BCF}$ & 0.33 & 0.01 & $<0.01$ & 0.05 & $<0.01$ & $<0.01$ & 0.25 & \\
\hline 3 & Soil & $2.13 \pm$ & $160.00 \pm$ & $61.33 \pm$ & $13.27 \pm$ & $80.67 \pm$ & $393.33 \pm$ & $390.00 \pm$ & $8.10 \pm$ \\
\hline & & $0.40^{\mathrm{a}}$ & $26.46^{\mathrm{b}}$ & $12.22^{\mathrm{b}}$ & $4.24^{\mathrm{c}}$ & $18.56^{\mathrm{b}}$ & $40.41^{\mathrm{a}}$ & $36.06^{\mathrm{a}}$ & $0.03^{\mathrm{A}}$ \\
\hline & $\mathrm{E} / \mathrm{w}$ & $0.92 \pm$ & $2.21 \pm$ & $0.31 \pm$ & $0.76 \pm$ & $0.27 \pm$ & $0.22 \pm$ & $69.19 \pm$ & \\
\hline & & $0.78^{\mathrm{a}}$ & $1.55^{\mathrm{a}}$ & 0.05 & $0.45^{\mathrm{a}}$ & $0.16^{\mathrm{a}}$ & $0.09^{\mathrm{a}}$ & $42.76^{\mathrm{a}}$ & \\
\hline & $\mathrm{BCF}$ & 0.43 & 0.01 & $<0.01$ & 0.06 & $<0.01$ & $<0.01$ & 0.18 & \\
\hline 4 & Soil & $2.40 \pm$ & $290.00 \pm$ & $72.00 \pm$ & $12.67 \pm$ & $99.00 \pm$ & $503.33 \pm$ & $323.33 \pm$ & $8.03 \pm$ \\
\hline & & $0.87^{\mathrm{a}}$ & $26.46^{\mathrm{b}}$ & $8.54^{\mathrm{b}}$ & $0.58^{\mathrm{c}}$ & $1.73^{b}$ & $56.86^{\mathrm{a}}$ & $37.86^{\mathrm{a}}$ & $0.04^{\mathrm{A}}$ \\
\hline & $\mathrm{E} / \mathrm{w}$ & $1.21 \pm$ & $3.28 \pm$ & $0.39 \pm$ & $0.99 \pm$ & $0.35 \pm$ & $0.26 \pm$ & $88.08 \pm$ & \\
\hline & & $0.54^{\mathrm{a}}$ & $0.83^{\mathrm{a}}$ & $0.13^{\mathrm{b}}$ & $0.29^{\mathrm{a}}$ & $0.16^{\mathrm{a}}$ & $0.13^{\mathrm{a}}$ & $13.98^{\mathrm{a}}$ & \\
\hline & $\mathrm{BCF}$ & 0.50 & 0.01 & $<0.01$ & 0.08 & $<0.01$ & $<0.01$ & 0.27 & \\
\hline 5 & Soil & $2.17 \pm$ & $203.33 \pm$ & $66.67 \pm$ & $17.67 \pm$ & $90.67 \pm$ & $403.33 \pm$ & $306.67 \pm$ & $7.89 \pm$ \\
\hline & & $0.23^{\mathrm{a}}$ & $23.09^{\mathrm{a}}$ & $10.21^{\mathrm{b}}$ & $1.15^{\mathrm{c}}$ & $9.02^{\mathrm{b}}$ & $20.82^{\mathrm{a}}$ & $30.55^{\mathrm{a}}$ & $0.08^{\mathrm{A}}$ \\
\hline & $\mathrm{E} / \mathrm{w}$ & $1.02 \pm$ & $3.35 \pm$ & $0.29 \pm$ & $0.82 \pm$ & $0.32 \pm$ & $0.19 \pm$ & $89.73 \pm$ & \\
\hline & & $0.67^{\mathrm{a}}$ & $0.86^{\mathrm{a}}$ & $0.02^{\mathrm{b}}$ & $0.20^{\mathrm{a}}$ & $0.14^{\mathrm{a}}$ & $0.07^{\mathrm{a}}$ & $16.09^{\mathrm{a}}$ & \\
\hline & $\mathrm{BCF}$ & 0.47 & 0.02 & $<0.01$ & 0.05 & $<0.01$ & $<0.01$ & 0.29 & \\
\hline 15 & Soil & $2.11 \pm$ & $176.67 \pm$ & $70.00 \pm$ & $10.30 \pm$ & $73.33 \pm$ & $400.00 \pm$ & $360.00 \pm$ & $8.02 \pm$ \\
\hline & & $0.93^{\mathrm{a}}$ & $11.55^{\mathrm{b}}$ & $3.46^{\mathrm{b}}$ & $0.61^{\mathrm{c}}$ & $0.58^{c}$ & $30.00^{\mathrm{a}}$ & $70.00^{\mathrm{a}}$ & $0.11^{\mathrm{A}}$ \\
\hline & $\mathrm{E} / \mathrm{w}$ & $1.08 \pm$ & $3.22 \pm$ & $0.38 \pm$ & $0.73 \pm$ & $0.19 \pm$ & $0.21 \pm$ & $91.83 \pm$ & \\
\hline & & $0.45^{\mathrm{a}}$ & $0.74^{\mathrm{a}}$ & $0.01^{\mathrm{b}}$ & $0.25^{\mathrm{a}}$ & $0.09^{a}$ & $0.09^{a}$ & $16.36^{\mathrm{a}}$ & \\
\hline & $\mathrm{BCF}$ & 0.43 & 0.02 & $<0.01$ & 0.07 & $<0.01$ & $<0.01$ & 0.26 & \\
\hline
\end{tabular}


Bioassays of soils collected from the field do, however, indicate how these metal mixtures, in conjunction with soil properties (e.g. pH), affect soil organisms and are environmentally more "realistic" than single toxicant studies.

\section{Conclusions}

Although most of the metals present in the soils studied were higher than the screening benchmarks [16] it is, however, extremely difficult to interpret the effects of these metals due to the fact that they are present in a mixture. Having stated this, the fact remains that it is possible to compare the relative toxicity of the soil, or rather the effects of the platinum TDF, along an increasing gradient on the basis of effects on earthworm mortality, growth and reproduction. Based on the data regarding growth it can therefore be concluded that TDFs of platinum mining only has a negative effect on earthworms up to $1 \mathrm{~km}$ and up to $5 \mathrm{~km}$ if reproduction is used as effect parameter. These effects on growth and reproduction can be attributed to the presence of metals in these soils, especially $\mathrm{Cr}, \mathrm{Cu}$ and $\mathrm{Ni}$ which were all found to be decreasing in concentration in a gradient away from the TDF.

The fact that the soils collected were from an industrially polluted area and that most metal concentrations were below ICs even on the TDF suggests that the impact of platinum mining on the environment is not too severe. Growth and reproduction data on E. fetida, however, suggested otherwise. In a study to biologically assess contaminated land using earthworms, Hankard et al. [12] found that effects manifested a cellular level of the worms despite the fact that metal concentration were below the ICs. Since the dynamics of metal mixtures are not fully understood yet, it should always be considered to do bioassays rather than base environmental impacts on chemical data alone. From the results presented it can therefore be concluded that platinum mining, with TDFs as source of contamination, has negative effects on the environment for up to $5 \mathrm{~km}$. Further studies between $5-15 \mathrm{~km}$ are, however, needed to assess the exact negative effects and it can further be concluded that the effects of platinum mining on the terrestrial environment is less than $15 \mathrm{~km}$ away from TDFs.

\section{REFERENCES}

[1] Van der Merwe, A.J., and Vosloo, J.I. (1992): Soil pollution - Action required. - Proc. Nat. Veld Trust Jubilee Congress.

[2] Van Wyk, S. (1994): 'n Strategie vir die rehabilitasie van versteurde mynbougebiede in Suidelike Afrika. - Ph.D. dissertation. Potchefstroom University for CHE, South Africa.

[3] Mbendi (2004): South Africa - Mining: Platinum Group Element Mining - Overview. http://www.mbendi.co.za/indy/ming/plat/af/sa/p0005.htm. [Date of access 25 January 2004].

[4] Van Rensburg, L., Morgenthal, T. (2004): The effect of woodchip waste on vegetation establishment during platinum tailings rehabilitation. - S. Afr. J. Sci. 100: 294-300.

[5] Department of Water Affairs and Forestry (1996): South African Water Quality Guidelines. Agricultural Use: Irrigation. Vol. 4. The Government Printer, Pretoria.

[6] Cook, N., Hendershot, W.H. (1996): The problem of establishing ecologically based soil quality criteria: The case of lead. - Can. J. Soil Sci. 76(3): 335-342.

[7] Van Gestel, C.A.M. (1997): Scientific basis for extrapolating results from soil ecotoxicity tests to field conditions and the use of bioassays. In: Ecological risk assessment of contaminants (N.M. van Straalen, and H. Lokke, eds), Chapman and Hall, London. 
[8] Norton, D. (1996): Earthworm bioassay protocol for soil toxicity screening. Washington State Department of Ecology. Publication no. 96-327.

[9] Keddy, C.J., Green, J.C., Bonnel, M.A. (1995): Review of whole-organism bioassays: Soil, freshwater sediment and freshwater assessment in Canada. - Ecotox. Environ. Saf. 30: 221-251.

[10] Haynes, R.J., Graham, M.H. (2004): Soil biology and biochemistry - a new direction for South African soil science? - S. Afr. J. Plant Soil. 21(5), 330-344.

[11] Cortet, J., Gomot-De Vauflery, A., Poinsot-Balaguer, N., Gomot, L., Texier, C., Cluzeau, D. (1999): The use of invertebrate soil fauna in monitoring pollutant effects. - Eur. J. Soil. Biol. 35: $115-134$.

[12] Hankard, P.K., Svendsen, C., Wright, J., Wienberg, C., Fishwick, S.K., Spurgeon, D.J., Weeks, J.M. (2004): Biological assessment of contaminated land using earthworm biomarkers in support of chemical analysis. - Sci. Total Environ. 330: 9-20.

[13] Morgan,A.J., Evans, M., Winters, C., Gane, M., Davies, M.S. (2002): Assaying the effects of chemical ameliorants with earthworms and plants exposed to a heavily polluted metalliferous soil. - Eur. J. Soil Biol. 38: 323-327.

[14] OPPTS (1996): Ecological effects test guidelines. Earthworm subchronic toxicity test. http://www.epa.gov/opptsfrs/OPPTS_Harmonized/850_Ecological_Effects_Test_Guideli nes/Drafts/850-6200.pdf [Date of access: 22 June 2004].

[15] Katz, S.A., Jennis, S.W. (1983): Regulatory compliance monitoring by atomic absorption spectroscopy. Verlag Chemie International, Florida.

[16] Efroymson, R.A., Will, M.E, Suter II, G.W. (1997): Toxicological Benchmarks for Contaminants of Potential Concern for Effects on Soil and Litter Invertebrates and Heterotrophic Processes: 1997 Revision. Oak Ridge National Laboratory, Oak Ridge TN. ES/ER/TM-126/R2

[17] Ministry of Housing, Spatial planning and Environment (VROM) (2000): Annexes A-D: Circular on target values and intervention values for soil remediation. http://www2.vrom.nl/docs/internationaal/annexS_I2000.pdf [Date of access 25 January 2004].

[18] Lock, K., Janssen, C.R. (2002): Ecotoxicity of chromium (III) to Eisenia fetida, Enchytraeus albidus, and Folsomia candida. Ecotoxicol. Environ. Safety 51: 203-205.

[19] Molnar, L., Fischer, E., Kallay, M. (1989): Laboratory studies on the effect, uptake and distribution of chromium in Eisenia foetida (Annelida, Oligochaeta). - Zool. Anz. 223: 57-66.

[20] Maboeta, M.S., Reinecke, A.J., Reinecke, S.A. (2003): Linking lysosomal biomarker and population responses in a field population of Aporrectodea caliginosa (Oligochaeta) exposed to the fungicide copper oxychloride. Ecotoxicol. Environ. Saf. 56 (3): 411-418.

[21] Spurgeon, D.J., and Hopkin, S.P. (1995): Extrapolation of the laboratory-based OECD earthworm toxicity test to metal-contaminated field sites. - Ecotoxicology 4: 190-205.

[22] Lock, K., Janssen, C.R. (2002): Ecotoxicity of nickel to Eisenia fetida, Enchytraeus albidus, and Folsomia candida. - Chemosphere 46: 197-200.

[23] Spurgeon, D.J., Hopkins, S.P., Jones, D.T. (1994): Effects of cadmium, copper, lead, and zinc on growth, reproduction and survival of the earthworm Eisenia fetida (Savigny): Assessing the environmental impact of point-source metal contamination in terrestrial ecosystems. -Environ. Pollut. 84: 123-130.

[24] Reinecke, A.J., Reinecke, S.A., Maboeta, M.S. (2001): Cocoon production and viability as endpoints in toxicity testing of heavy metals with three earthworm species. Pedobiologia 45: 61-68. 